Boletín de la Sociedad Geológica Mexicana

VOLUMEN 65, NÚM. 3, 2013, P. 527-531

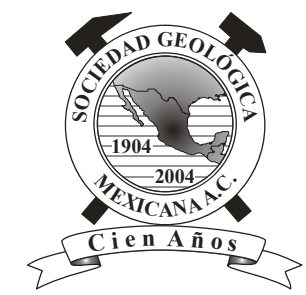

\title{
First record of Duvalia ex. gr. lata (Cephalopoda, Coleoidea) from Mexico
}

\author{
Patrick Zell1, ${ }^{1,}$, Seija Beckmann ${ }^{1}$, Wolfgang Stinnesbeck ${ }^{1}$, José Flores-Ventura ${ }^{2}$ \\ ${ }^{1}$ Institute for Earth Sciences, Heidelberg University, Im Neuenheimer Feld 234, 69120 Heidelberg, Germany. \\ ${ }^{2}$ Santa Engracia 257, Fracc. Santa Elena, Saltillo C.P. 25015, Coahuila, México. \\ *Patrick.Zell@geow.uni-heidelberg.de
}

\begin{abstract}
Here we present the first record of the belemnite Duvalia ex. gr. lata (Cephalopoda, Coleoidea) from Mexico. The unique individual, a well-preserved rostrum, was discovered in Early Cretaceous strata of the Sierra de Parras close to Viesca in southwestern Coahuila. Duvalia ex. gr. lata was previously known from the Mediterranean Tethys. Our report extends the paleogeographic distribution of Duvalia to the western hemisphere and supports the hypothesis that the Hispanic Corridor was open during the Early Cretaceous, allowing for marine faunal exchange and migration between the Gulf of Mexico and the European Tethys.
\end{abstract}

Keywords: Duvalia, belemnite, Early Cretaceous, Mexico, Hispanic Corridor.

\section{Resumen}

Se reporta por primera vez el belemnite Duvalia ex. gr. lata (Cephalopoda, Coleoidea) en México. El único ejemplar, un rostro bien preservado, ha sido descubierto en capas del Cretácico Temprano de la Sierra de Parras, en las cercanías de Viesca, en el suroeste de Coahuila. Previamente, se conocía a Duvalia ex. gr. lata en el Tethys de la region mediterránea. Nuestro reporte extiende la distribución de Duvalia al hemisferio occidental y apoya la hipótesis de que el Corredor Hispánico permaneció abierto durante el Cretácico Temprano, lo cual permitió el intercambio de fauna marina y migraciones entre el Golfo de México y el Tethys europeo.

Palabras clave: Duvalia, belemnite, Cretácico Temprano, México, Corredor Hispánico.

\section{Introduction}

Reports on belemnites (Coleoidea, Cephalopoda) from Mexico are rather scarce. Only Albian, and to a lesser extent Aptian neohibolitid belemnites, are well known (Kellum, 1937; Seibertz and Buitrón, 1987; Spaeth, 1988; Seibertz and Spaeth, 1999, 2000, 2002, 2005, 2009). In addition, Late Jurassic belemnites are regularly mentioned (del Castillo and Aguilera, 1895; Burckhardt, 1930; Rogers et al., 1956; Tardy, 1972; Hose, 1981; Seibertz and Spaeth, $1999,2009)$ but generally lack specific identification. Neocomian belemnites appear to be nearly absent except for some Hibolithes (Seibertz and Spaeth, 1999, 2000; Angeles-Villeda, 2004). An overview of Mexican Jurassic and Cretaceous belemnites was given by Seibertz and Spaeth (1999, 2000, 2008, 2009). All Early Cretaceous belemnites belong to the Mesohibolitidae, while the Duvaliidae, except for citations by Seibertz and Spaeth (2000, 2008), appear to be unknown in Mexico.

Here we report the first record of Duvalia ex. gr. lata from Mexico. The genus is well known and is also a common component in the Mediterranean and IndoPacific faunal Provinces from Bathonian to Aptian times (Late Jurassic - Early Cretaceous), but was hitherto rarely mentioned from the western hemisphere (Pugaczewska, 1961; Stevens, 1965; Combémorel, 1988, 1997; Mutterlose, 1992; Seibertz and Spaeth, 2008). 


\section{Material and preservation}

The Mexican specimen is a well-preserved rostrum which was collected by one of the authors (J.F.V.) in marine sediments of the lower Tamaulipas Formation, a carbonate dominated sediment sequence of hemipelagic origin, in the southwestern part of the Sierra de Parras, about $30 \mathrm{~km}$ northeast of the village of Viesca in southwestern Coahuila $\left(25^{\circ} 24.103^{\prime} \mathrm{N}-102^{\circ} 32.290^{\prime} \mathrm{E}\right)$ (Figure 1). The precise layer of origin is not known, but associated ammonites such as Olcostephanus, would suggest an early Valanginian to early Hauterivian age. According to Imlay $(1938,1940)$ and Cantú-Chapa (2009, 2012), occurrences of Olcostephanus in Mexico are restricted to this stratigraphic interval. This interpretation is supported by the belemnite described herein. The Mexican specimen of Duvalia is related to the species-group of Duvalia lata (de Blainville, 1827), a taxon known from the late Berriasian and early Valanginian of the Mediterranean Tethys.

\section{Systematic paleotology}

The specimen of Duvalia presented here is deposited in the Museo del Desierto, Saltillo, Coahuila, Mexico (CPC, Colección de Paleontología de Coahuila - storage number CPC-941).

Class Cephalopoda Cuvier, 1795

Subclass Coleoidea Bather, 1888

Order Belemnitida Zittel, 1895
Suborder Pachybelemnopseina Riegraf, 1998

Family Duvaliidae Pavlow, 1914

Genus Duvalia Bayle, 1878

Type species: Belemnites dilatatus de Blainville, 1827

Duvalia ex. gr. lata (de Blainville, 1827)

Figure 2a-f

\subsection{Material}

One rostrum (CPC-941).

\subsection{Diagnosis}

A medium-sized and laterally compressed rostrum with a dorsal alveolar groove. The apex is pointed and the alveolar area straight, with a shallow alveolus. The cross-section is rounded in the apical half of the rostrum but gradually becomes hexagonal and more laterally compressed towards the alveolar area.

\subsection{Description}

The rostrum is $41 \mathrm{~mm}$ long, up to $10.5 \mathrm{~mm}$ high and $7.2 \mathrm{~mm}$ wide. It is laterally compressed and presents a long and distinct dorsal groove. The apical region is pointed and the apex is incurved towards the dorsal side. Typically, as in most species that relate to D. lata, in lateral view, the dorsal side gently curves both into the apical as well as the

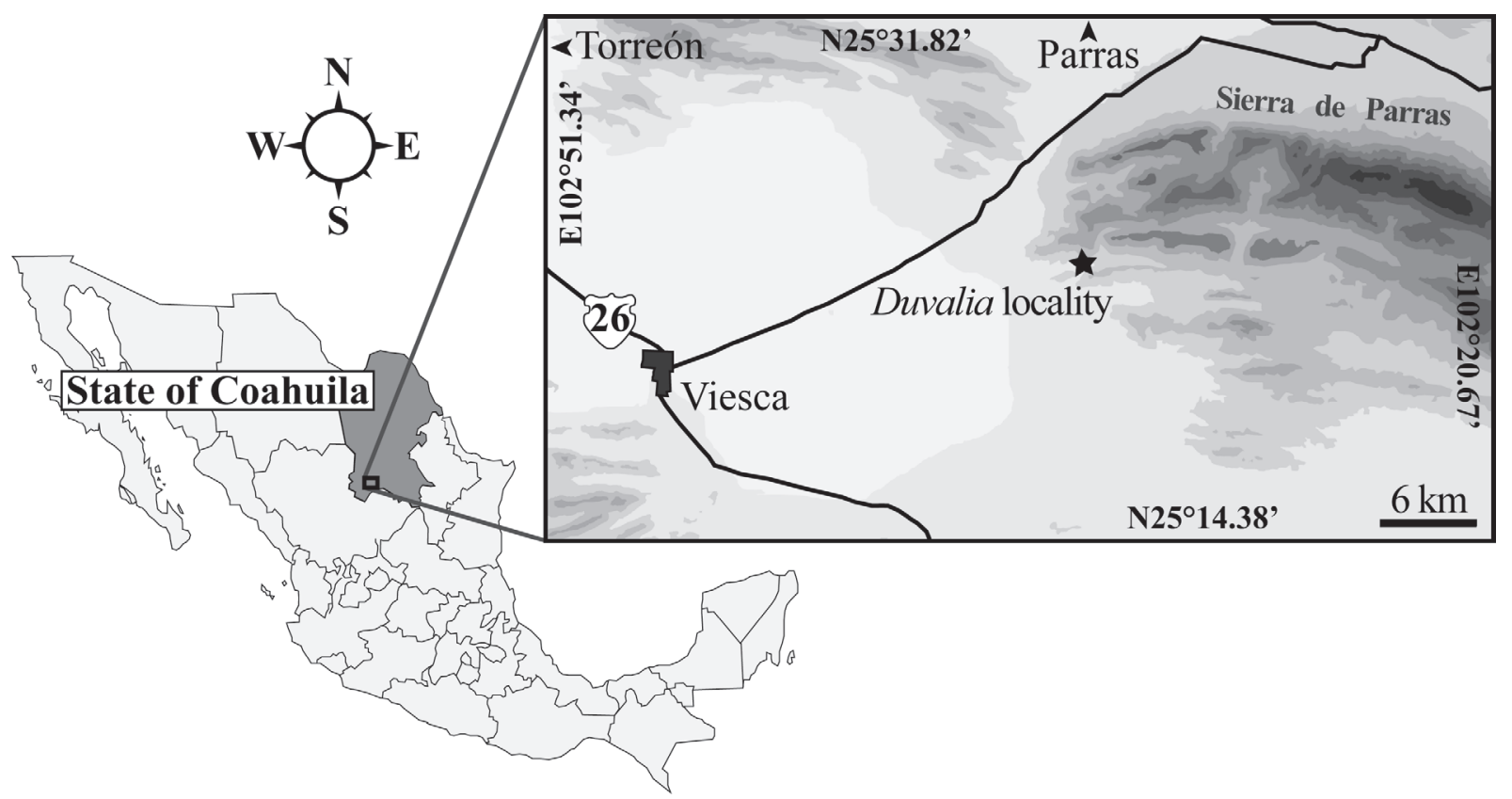

Figure 1. Map of Mexico with inset of northeastern Mexico. The fossil locality which yielded Duvalia ex. gr. lata is marked with a star. Base map of Mexico simplified after Instituto Nacional de Estadística y Geografía (INEGI, 2013)., Fotos y Mapas Virtuales, 2001, Interactive and Panoramic Maps of Mexico, Nuevo León State, Mexico map in 16 zoomable tiles or sections: California. Fotos y Mapas Virtuales, S.A. de C.V., 1 map, online: URL: http:// www.maps-of-mexico.com/nuevo-leon-state-mexico/nuevo-leon-state-mexico-map-main.shtml (status 06/05/2013). 
a)

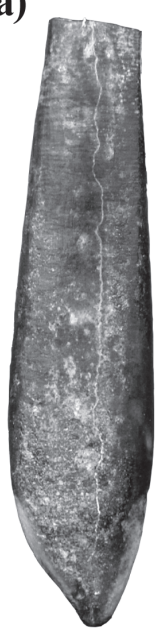

b)

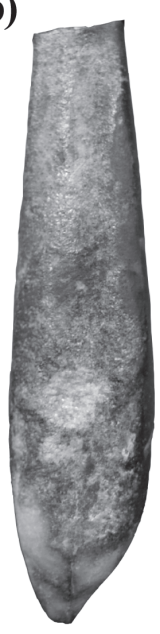

c)

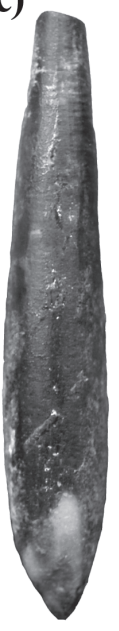

d)

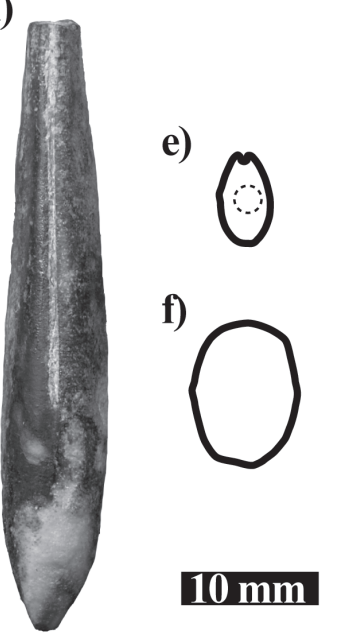

Figure 2. Duvalia ex. gr. lata (de Blainville, 1827) from the Lower Tamaulipas Formation at Viesca, northeast Mexico. a) Right lateral view. b) Left lateral view. c) Ventral view. d) Dorsal view. e) Cross-section at alveolar opening. Dashed line indicates position of the phragmocone. f) Cross-section at mid-part of rostrum.

alveolar side, while the ventral side incurves much more rapidly towards the apex. Laterally, the rostrum shows a faint ridge located in the middle of the flank, which gradually increases in strength towards the alveolar part. As a result, the laterally flattened cross-section becomes increasingly hexagonal towards the alveolar opening. The alveolus is shallow. In both dorsal and ventral outlines, the rostrum is fusiform.

\subsection{Remarks}

The subspecies Duvalia lata constricta Uhlig, 1902, from the latest Berriasian of Río Argos (Murcia, Spain), revised by Janssen (2003, pl. 6, figs. 12-13), resembles our specimen. Its guard has a comparable duvaliid outline and a dorsal groove with comparable structure. The apex is oriented towards the dorsal side and the lateral sides are parallel to convex. Duvalia lata de Blainville, 1827, from the Berriasian-lower Valanginian of Río Argos (Murcia, Spain) figured by Janssen (1997, p. 21-23, pl. 1, figs. 1-2) presents an alveolus which is deeper than in the Mexican specimen; the rostrum outline is more cylindrical and no characteristic constriction of the guard is present in the anterior part.

\subsection{Occurrence}

Duvalia ex. gr. lata is an important faunal element of the Mediterranean Tethys and ranges from late Tithonianlowermost upper Valanginian as summarized by Janssen (1997) and Alsen and Mutterlose (2009).

The Mexican specimen was collected from the surface and likely weathered out of limestone and shale of the lower Tamaulipas Formation. The precise layer of origin is not known, but goethized inner whorls of ammonites collected at close distances to the belemnite rostrum are likely a result from the same sediment layer. They include Olcostephanus, an early Valanginian to early Hauterivian ammonite genus (Imlay, 1938, 1940; Cantú-Chapa, 2009, 2012).

\section{Discussion and conclusion}

The Duvaliidae originated during the Bathonian (Middle Jurassic) in the central Tethys (Doyle et al., 1994). During the Late Jurassic and Early Cretaceous, members of the family migrated southwards and reached Madagascar (Combémorel, 1988), and Antarctica (Mutterlose, 1986, 1988; Challinor and Hikuroa, 2007). Duvalia hispanica has been found by Seibertz (pers. com.) in ValanginianHauterivian strata of the Cape Verde Island Maio, which confirms a migration pathway of duvaliids along the southern border of the Hispanic Corridor westwards into Mexico. The paleobiogeographic distribution of the genus Duvalia was summarized by Mutterlose (1992) and is shown in Figure 3 (with additional data from Mutterlose and Wiedenroth, 2008; Alsen and Mutterlose, 2009; Janssen (pers. com.); Seibertz (pers. com.)).

Our specimen thus provides the first record of Duvalia ex. gr. lata in Mexico, which extends the paleogeographic distribution of this species to the western hemisphere. Our result supports the interpretation of an Early Cretaceous faunal connection between the Mediterranean Tethys and the Gulf of Mexico region. This migratory pathway, known as the Hispanic Corridor, has been postulated by Damborenea (2000) and Aberhan (2001). The latter is demonstrated by conspecific occurrences of ammonites (e.g. Fözy, 2004; Barragán and Maurasse, 2008; Cantú Chapa, 2009), belemnites (e.g. Seibertz and Spaeth, 2008), calpionellids (e.g. Trejo, 1960; Adatte et al., 1994, 1996), and other taxa on both sides of the North Atlantic. The occurrence of 


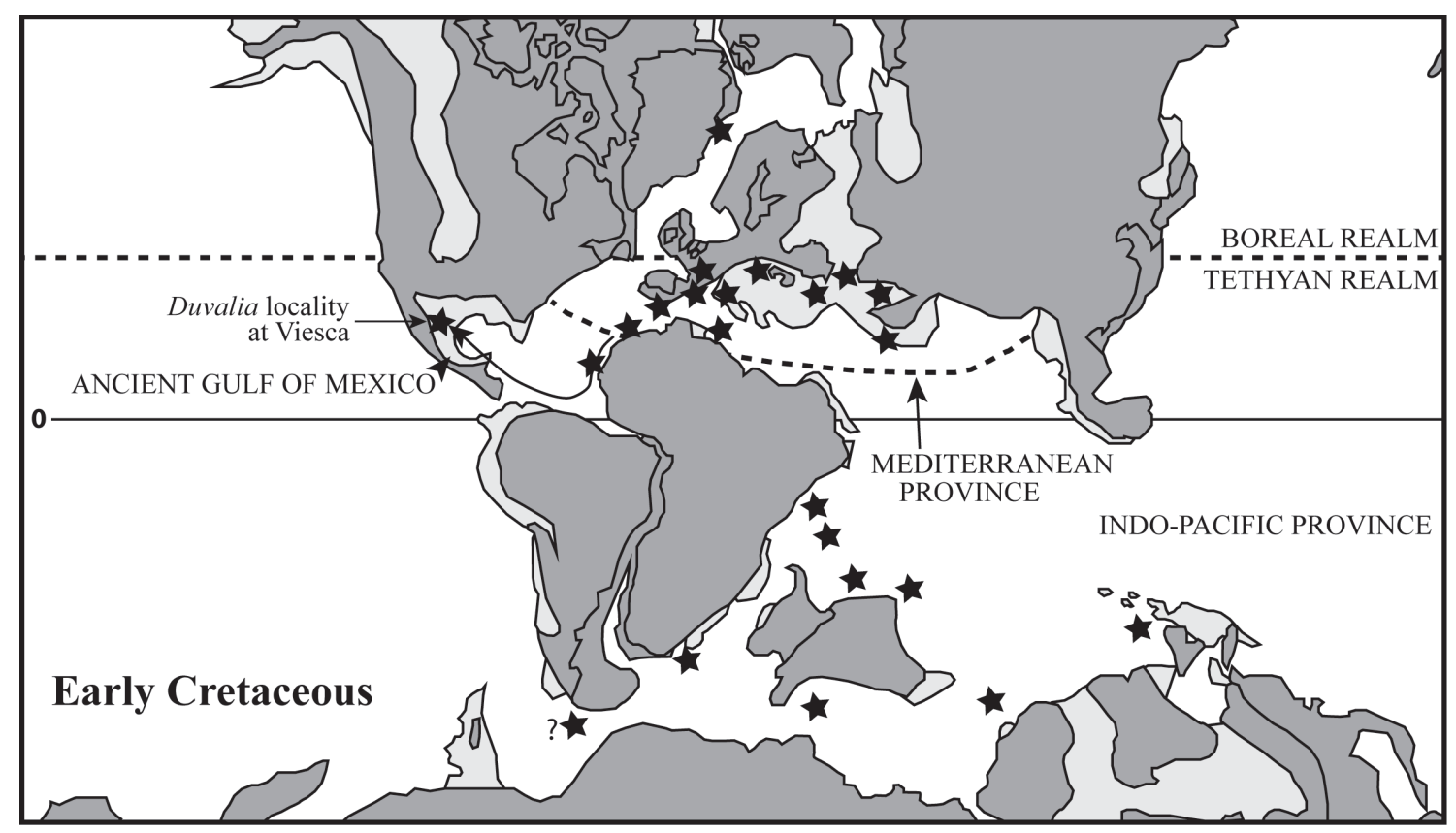

Figure 3. Paleobiogeography of Duvalia during the Early Cretaceous (Berriasian-Barremian). Fossil localities are marked with an asterisk (distribution summarized after Mutterlose, 1992; Mutterlose and Wiedenroth, 2008; Alsen and Mutterlose, 2009; Janssen pers. com.; Seibertz pers. com.). Plate tectonic configuration simplified after Barron et al. (1981). The arrow indicates a possible migration path between the Mediterranean Tethys Province and the Gulf of Mexico region.

Duvalia ex. gr. lata gives additional evidence to support this faunal exchange during the Early Valanginian.

\section{Acknowledgements}

We acknowledge Ekbert Seibertz and Nico Janssen for their constructive reviews and Angelika Hering, Fabio Hering, Roland Hering, Carolin Möbus, Isabell Hubert and Dominik Schmithüsen for additional comments on this manuscript. Financial support of this research was provided by Deutsche Forschungsgemeinschaft (DFG) grant STI12817 and Heidelberg University Graduate Academy grant LGFG 2012-9 (to P.Z.).

\section{References}

Aberhan, M., 2001, Bivalve palaeobiogeography and the Hispanic Corridor: time of opening and effectiveness of a proto-Atlantic seaway: Palaeogeography, Palaeoclimatology, Palaeoecology, 165, 375-394.

Adatte, T., Stinnesbeck, W., Remane, J., 1994, The Jurassic-Cretaceous boundary in Northeastern Mexico. Confrontation and correlations by microfacies, clay minerals mineralogy, calpionellids and ammonites: Geobios, 27, 37-56.

Adatte, T., Stinnesbeck, W., Remane, J., Hubberten, H., 1996, Paleoceanographic changes at the Jurassic-Cretaceous boundary in the Western Tethys, northeastern Mexico: Cretaceous Research, 17, 671-689.

Alsen, P., Mutterlose, J., 2009, The Early Cretaceous of North-East Greenland: A crossroads of belemnite migration: Palaeogeography, Palaeoclimatology, Palaeoecology, 280, 168-182.
Angeles-Villeda, M.E., 2004, Paleoecología y bioestratigrafía del contacto entre las formaciones la Casita y Taraises en la Sierra de Minas Viejas, al noroeste de Monterrey, Nuevo León, México: Nuevo León, México, Universidad Autónoma de Nuevo León, Facultad de Ciencias Biológicas, MSc dissertation, $90 \mathrm{p}$.

Barragán, R., Maurrasse, F.J-M.R., 2008, Lower Aptian (Lower Cretaceous) ammonites from the basal strata of the La Peña Formation of Nuevo León State, northeast Mexico: biochronostratigraphic implications: Revista Mexicana de Ciencias Geológicas, 25, 145-157.

Barron, E.J., Harrison, C.G.A., Sloan II, J.L., Hay, W.W., 1981, Paleogeography, 180 million years ago to the present: Eclogae Geologicae Helvetiae, 74, 443-470.

Bather, F.A., 1888, Shell growth in Cephalopoda (Siphonopoda): Annals and Magazine of Natural History (series 6), 1, 298-310.

Bayle, E., 1878, Fossiles principaux des terrains, in Bayle, E., Zeiller, R. (eds.), Explication de la carte géologique de France (4), 1 (Atlas), Imprimerie Nationale, Paris, 176 pls.

Blainville, H.-M. Ducrotay, de, 1827, Mémoire sur les Bélemnites, considérées zoologiquement et géologiquement: Levrault, Paris, 136 p.) to (de Blainville, H.-M. Ducrotay, 1827, Mémoire sur les Bélemnites, considérées zoologiquement et géologiquement: Levrault, Paris, $136 \mathrm{p}$.

Burckhardt, C., 1930, Etude synthétique sur le Mésozoïque mexicain: Mémoires de la Société Paléontologique Suisse, 49(4) + 50(1), 280 p.

Cantú-Chapa, A., 2009, Ammonites of the Cretaceous Taraises and lower Tamaulipas formations in eastern Mexico, in Bartolini, C., Román Ramos, J.R. (eds.), Petroleum systems in the southern Gulf of Mexico: American Association of Petroleum Geologists, Memoir, 90, 191-216.

Cantú-Chapa, A., 2012, The suture line patterns in olcostephanidae and spiticeratidae, ammonites of the Upper Jurassic-Lower Cretaceous: Systematic considerations: Paleontología Mexicana, 62, 52-66.

Challinor, A.B., Hikuroa, C.H., 2007, New Middle and Upper Jurassic belemnite assemblages from West Antarctica (Latady Group, Ellsworth Land): Taxonomy and paleobiogeography: Palaeontologia Electronica, 10, 1-29. 
Combémorel, R., 1988, Les bélemnites de Madagascar: Documents de la Laboratoire de Géologie de la Faculté des Sciences de Lyon, $104,239 \mathrm{p}$

Combémorel, R., 1997, Bélemnites: Bulletin du Centre de Recherches Elf Exploration Production, Mémoires, 17, 157-167.

Cuvier, G.L.C.F.D., 1795, Second mémoire sur l'organization et les rapports des animaux à sang blanc, dans lequel on traite de la structure des Mollusques et de leur division en ordre: Magazin Encyclopédique, ou Journal des Sciences, des Lettres et des Arts (Année 1), 2, 433-449.

Damborenea, S.E., 2000, Hispanic corridor: Its evolution and the biogeography of bivalve molluscs, in Hall, R.L., Smith, P.L. (eds.), Advances in Jurassic Research 2000: GeoResearch Forum, 6, 369-380.

Del Castillo, A., Aguilera, J.G., 1895, Primeros estudios de la fauna fósil de la serranía mineral de Catorce en San Luis Potosí. Fauna fósil de la Sierra de Catorce (San Luis Potosí): Boletín de la Comision Geológica de México, 1, 55 p.

Doyle, P., Donovan, D.T., Nixon, M., 1994, Phylogeny and systematics of the Coleoidea: The University of Kansas, Paleontological Contributions $5,15 \mathrm{p}$.

Fözy, I., 2004, The Early Cretaceous ammonite genus Oosterella Kilian, 1911 in Hungary: Fragmenta Palaeontologica Hungarica, Budapest, 22, 51-62.

Hose, L.D., 1981, The geology and hydrogeology of the Sistema Purificacion Area, Villa Hidalgo, Tamaulipas, Mexico: Los Angeles, Faculty of the Department of Geology of the California State University, MSc dissertation, $148 \mathrm{p}$.

Imlay, R.W., 1938, Ammonites of the Taraises Formation of Northern Mexico: Geological Society of America Bulletin, 49, 539-602.

Imlay, R.W., 1940, Neocomian faunas of Northern Mexico: Geological Society of America Bulletin, 51, 117-190.

Instituto Nacional de Estadística y Geografía (INEGI), 2013, Mapa Digital: México. D.F. Secretaría de Programación y Presupuesto, Instituto Nacional de Estadística, Geografía e Informática, 1 map, online: URL: http://www.inegi.org.mx (status 23/05/2013).

Janssen, N.M.M., Kahabasze, M.V., Hoedemaeker, P.J., 1997, Mediterranean Neocomian belemnites, part 1: Río Argos sequence (province of Murcia, Spain): the Berriasian-Valanginian and the Hauterivian-Barremian boundaries: Scripta Geologica, 114, 1-55.

Janssen, N.M.M., 2003, Mediterranean Neocomian belemnites, part 2: the Berriasian-Valanginian boundary in southeast Spain (Río Argos, Cañada Lengua and Tornajo): Scripta Geologica, 126, 121-183.

Kellum, L.B., 1937, Geology of the sedimentary rocks of the San Carlos Mountains, in Kellum, L.B. (dir.), The geology and biology of the San Carlos Mountains, Tamaulipas, Mexico: Ann Arbor, Michigan, U.S.A., University of Michigan Press, Reports of the University of Michigan expedition to the San Carlos Mountains in 1930, 1-98.

Mutterlose, J., 1986, Upper Jurassic belemnites from the Orville Coast, Western Antarctica, and their paleobiogeographical significance: British Antarctic Survey Bulletin, 70, 1-22.

Mutterlose, J., 1988, Migration and evolution patterns in Upper Jurassic and Lower Cretaceous belemnites, in Wiedmann, J., Kullmann, J. (eds.), Cephalopods - Present and Past, E. Schweizerbart'sche Verlagsbuchhandlung, Stuttgart, 525-537.

Mutterlose, J., 1992, Early Cretaceous belemnites from the East Indian Ocean and their paleobiogeographic implications: Proceedings of the Ocean Drilling Program, Scientific Results, 123, 443-450.

Mutterlose, J., Wiedenroth, K., 2008, Early Cretaceous (ValanginianHauterivian) belemnites from western Morocco: stratigraphy and palaeoecology: Cretaceous Research, 29, 814-829.

Pavlow, A.P., 1914, Юрскія и нижнемеловыя серhalopoda северной Сибири [Jurassic and early Cretaceous cephalopods from northern Siberia] (in Russian): Записки Императорской Академіи Наукъ [Mémoires of the Imperial Academy of Sciences] (series 8 физикоматематическому отделенію), 21, 68 p.

Pugaczewska, H., 1961, Belemnoids from the Jurassic of Poland: Acta Paleontologica Polonica, 6, 105-263.
Riegraf, W., Janssen, N.M.M., Schmitt-Riegraf, C., 1998, Cephalopoda dibranchiata fossils (Coleoidea) II, in Westphal, F. (ed.), Fossilium Catalogus. I: Animalia: Leiden, Backhuys Publishers, 135, 512 p.

Rogers, C.L., Cserna, Z. De, Tavera, E., Ulloa, S., 1956, General geology and phosphate deposits of Concepción del Oro District, Zacatecas, Mexico. Geological Investigations in the American Republics: Washington, United States Government Printing Office, Geological Survey Bulletin 1037-A, 102 p.

Seibertz, E., Buitrón, B.E., 1987, Paleontología y estratigrafía de los Neohibolites del Albiano de Tepexi de Rodriguez, Estado de Puebla (Cretácico medio, México): Revista de la Sociedad Mexicana de Paleontologia, 1, 285-299.

Seibertz, E., Spaeth, C., 1999, Range and distribution of belemnites in the Jurassic and Cretaceous of Mexico - a progress report, in Histon, K. (ed.), Abstracts Volume of the V International Symposium: Cephalopods - Present and Past: Vienna, Austria, Berichte der Geologischen Bundesanstalt, 46, 102 p.

Seibertz, E., Spaeth, C., 2000, Range and distribution of belemnites in the Cretaceous of northcentral Mexico. Abstracts book of the 6th International Cretaceous Symposium: Vienna, Austria, $125 \mathrm{p}$.

Seibertz, E., Spaeth, C., 2002, Cretaceous belemnites of Mexico III. The Albian Neo- and Mesohibolites of the "Mexican Solnhofen" Tepexi de Rodríguez (State of Puebla) and their biostratonomy (Lower Cretaceous): Neues Jahrbuch für Geologie und Paläontologie (Abhandlungen), 225, 55-74.

Seibertz, E., Spaeth, C., 2005, Cretaceous belemnites of Mexico IV. Mexican Mesohibolites and paleobiogeographical implications on the distribution of the genus (Albian, Lower Cretaceous): Neues Jahrbuch für Geologie und Paläontologie (Abhandlungen), 236, 95-113.

Seibertz, E., Spaeth, C., 2008, Belemnites (Coleoid cephalopods) in Jurassic and Cretaceous strata of Mexico: state of the art, II Simposio Geocientífico Internacional Linares, Resúmenes, Universidad Autónoma de Nuevo León, Facultad de Ciencias de la Tierra, México, 204-206.

Seibertz, E., Spaeth, C., 2009, Belemnites in shallow water carbonates of the Sierra de La Silla (Lower Cretaceous, Nuevo León, NE Mexico), in Wörner, G., Möller-McNett, S. (eds.), Abstracts and Program, International Lateinamerika-Kolloquium 2009, Geowissenschaftliches Zentrum der Universität Göttingen, April 7-9, 260-261.

Spaeth, C., 1988, Los belemnites Cretácicos de Mexico. I. Belemnites característicos de la Formación La Peña (Aptiano superior, "Gargasianno") en el noreste de México: Actas de la Facultad de Ciencias de la Tierra de la Universidad Autónoma de Nuevo León, $3,31-41$.

Stevens, G.R., 1965, The Jurassic and Cretaceous belemnites of New Zealand and a review of the Jurassic and Cretaceous belemnites of the Indo-Pacific region: New Zealand, New Zealand Geological Survey, Paleontological Bulletin, 36, $238 \mathrm{p}$.

Tardy, M., 1972, Sobre la estratigrafia de la Sierra Madre Oriental en el Sector de Parras Coahuila: Distincion de las Sieries Coahuilense y Parrense: Boletín de la Sociedad Geológica Mexicana, 33, 51-70.

Trejo, H.M., 1960, La familia Nannoconidae y su alcance estratigráfico en América: Boletín de la Asociación Mexicana de Geólogos Petroleros, 12, 259-314.

Uhlig, V.K., 1902, Über die Cephalopodenfauna der Teschener und Grodischter Schichten: Denkschriften der kaiserlichen Akademie der Wissenschaft, Mathematisch Naturwissenschaftliche Klasse, Wien, 72 (1901), 87 p., 9 pls.

Zittel, K.A., von, 1895, Grundzüge der Palaeontologie (Palaeozoologie): München, Leipzig, R. Oldenburg, 7, 971 p.

Manuscript received: July 19, 2013.

Corrected manuscript received: August 12, 2013.

Manuscript accepted: August 13, 2013. 